\title{
DO THE PARTIES OR THE PEOPLE OWN THE ELECTORAL PROCESS?
}

\author{
RICHARD L. HASEN ${ }^{\dagger}$
}

The editors of the University of Pennsylvania Law Review kindly asked me to comment, in light of the Supreme Court's recent decision in California Democratic Party v. Jones, ${ }^{1}$ on the question: "Should courts protect political parties in the two-party system?" In Jones, the Supreme Court struck down as unconstitutional Proposition 198 , a California voter initiative establishing a "blanket primary" that allowed voters, regardless of their party affiliation, to vote for any party's candidate in a primary election. For example, under a blanket primary a voter registered as a Democrat or Independent could vote for a Republican gubernatorial candidate to run in the general election. The Court held that the blanket primary violated the parties' First Amendment rights "by forcing political parties to associate with those who do not share their beliefs."

Assuming that the term "political parties" in the Law Review's question refers to political party organizations," my answer is that courts generally should not protect the two major political parties, the Democrats and Republicans, except from interference in each party's internal governance and from one party's attempt to gain partisan advantage over the other. On the other hand, courts should protect minor political parties. In the specific context of Jones, I argue that the major parties should not have been allowed to block a voter initiative establishing a blanket primary but that the minor parties probably should be constitutionally exempt from participating in it.

I begin Part I with a summary of my argument from an earlier

† Professor and William M. Rains Fellow, Loyola Law School. B.A. 1986, University of California, Berkeley; M.A. 1988, J.D. 1991, Ph.D. (Political Science) 1992, University of California, Los Angeles. Thanks to Rick Pildes, Mark Rush, and Roy Schotland for useful comments and suggestions.

120 S. Ct. 2402 (2000).

Id. at 2414. I will refer to this right not to associate as a right to "party autonomy." Ste Cal. Democratic Party v. Jones, 169 F.3d 646, app. at 659 n.28 (9th Cir. 1999) (stating that Professor Bruce Cain's greatest concern is protecting "party autonomy"), m'd, 120 S. Ct. 2402 (2000).

"It could alternatively refer to the party-in-government or the party-in-theelectorate, as explained in Part I.B below. 
article that the major political parties usually do not deserve or need protection from the courts, although they indeed receive such protection. ${ }^{4}$ My prior argument contended that the state should not be allowed to defend a law infringing upon the First Amendment rights of minor parties or independent candidates by claiming that such a law protects "the two-party system."

My prior argument does not resolve Jones, however, because in Jones the two major parties advanced their own claims to First Amendment protection from the state. The Supreme Court in Jones recognized the major parties' First Amendment right to autonomy, giving the parties the last word on the form of political primaries used to pick party nominees to run in the general election. ${ }^{5}$ I argue that Jones was decided incorrectly. Although parties have a First Amendment right to control their internal affairs, primaries are not internal party affairs. Rather, primaries are a means for voters to structure the electoral process by winnowing down candidates to a list of finalists to run in the general election. Voters through the initiative process or the state legislature should be allowed to dictate the form of that winnowing process, and they may reasonably choose the form of a blanket primary, a form which likely produces more moderate candidates to run in the general election.

After exploring the relationship between voters and party organizations in the current electoral system, I debunk a number of arguments that a blanket primary infringes on the First Amendment rights of major party organizations. My argument does not mean that states inevitably will adopt blanket primaries or other anti-party measures; major parties remain potent, perhaps the most potent, political forces in each state and their views often will carry the day in political battles, such as battles over the form of a primary.

In contrast to Part I, Part II explains that courts should generally protect minor parties from state regulation. Minor party organizations lack the structural and legal advantages enjoyed by the major political parties and need judicial protection as "discrete and insular minorities" to preserve their distinctive message and mission. The state also has less of a reason to regulate minor political parties. Finally, minor parties serve an important electoral function in raising

* Richard L. Hasen, Entrenching the Duopoly: Why the Supreme Court Should Not Allow the States to Protect the Democrats and Republicans from Political Competition, 1997 SUP. CT. REV. 331.

${ }^{5}$ Jones, 120 S. Ct. at 2408 (stating that a party's First Amendment right to limit control of its decisions is most important when selecting a nominee). 
issues not otherwise considered by major party candidates. ${ }^{6}$

Ultimately, the question whether courts should protect major parties' autonomy in elections reduces to a question of who controls the electoral process, major party organizations or the people. My vote is with the people, and I therefore fully concur with the claim that my position is a populist or progressive one.?

\section{The CASE AgaINST COURT PRotection OF MAJOR PARTIES AND THE "TWO-PARTY SYSTEN"}

\section{A. The Conventional Wisdom on the Benefits of the Two-Party System and the Supreme Court's Embrace of That Wisdom ${ }^{s}$}

In 1942, political scientist E.E. Schattschneider remarked that "modern democracy is unthinkable save in terms of the parties." Since that time, American political scientists dubbed the "responsible party government scholars" have concurred that strong political parties are indispensable to democratic government. ${ }^{10}$ They see

"The Brennan Center Brief similarly distinguished major and minor political parties' right to party autonomy. Brief for the Brennan Center for Justice at New York University School of Law as Amicus Curiae in Support of Neither Party, Cal. Democratic Party' v. Jones, 120 S. C. 2402 (2000) (No. 99-401), available at http:// wrw.brennancenter.org/resources/downloads/CADem.pdf (last visited Oct. 21, 2000) [hereinafter Brennan Center Brief]. The Center's analysis differs from my analysis here. The Brennan Center urged the Court to balance the major parties" "real" autonomy interest with state efforts to "involv[e] the entire electorate in the process of ulecting those who will serve as government officials." Id. at 8; see also id. at 22 ("The thate has a compelling interest in fostering participation by the governed (i.e., adding to rather than subtracting from the totality of First Amendment activity in California politics) in elections that determine who will be their governors."). I argue that the major parties have no right to party autonomy in public affairs like primaries, even though they have First Amendment rights in conducting their internal affairs.

My position on court protection of minor political parties essentially agrees with the Brennan Center"s position, see id. at 8 ("The lack of a compelling interest in opening the nomination process of minor parties to outsiders, coupled with the enhanced interest in autonomy enjoyed by ideologically defined minor parties, renders the involuntary application of open or blanket primaries to such parties unconstitutional."), though I am a bit tentative about the result in Jones and am not conxinced that the blanket primary undermines minor parties' autonomy.

'St Nathaniel Persily \& Bruce E. Cain, The Legal Status of Political Parties: A Rurcisssment of Competing Paradigms, 100 CoLUM. L. REv. 775, 785-87 (2000) (commenting that modern-day progressives favor state initiatives which reduce the significance of parties in elections).

"Parts I.A and I.B draw upon my more extended discussion of these issues in Hasen, supra note 4.

"E.E. SCHATTSCHNEIDER, PARTY GOVERNAIENT 1 (1942).

"Sir, r.g., V.O. Key, JR., POLITICS, PARTIES, \& PRESSURE Groups 9 (5th ed. 1964) 
political parties, and the American two-party system in particular, as promoting three important interests.

First, they argue that the two-party system promotes political stability." Under this theory, the two-party system creates extremely large coalitions embodied by the parties. The parties as coalitions are able to accommodate a large number of diverse groups and viewpoints without being overly influenced by any one of them. Strong parties also make government more accountable by allowing parties to take the credit for positive government output and blame for negative output. Lastly, political stability results from both parties gravitating toward the center to attract the median voter.

Second, they argue that the two-party system minimizes the power of factions. ${ }^{12}$ If strong parties form encompassing coalitions that take into account the views of many interest groups, weak political parties allow elected officials to be swayed by interest groups pursuing narrow agendas. Factionalism not only undermines political stability, but it also leads to government gridlock and causes voters to lose confidence in the democratic system.

Finally, responsible party government scholars declare that the party system provides an important voting cue for voters. ${ }^{13}$ As Larry Sabato explains, "party affiliation provides a useful cue for voters, particularly the least informed and interested, who can use party as a shortcut or substitute for interpreting issues and events they may little

("[Parties] perform the function of the articulation of the interests and aspirations of a substantial segment of the citizenry, usually in ways contended to be promotive of the national weal."). The belief received its most explicit expression in the American Political Science Association (APSA) report, Toward a More Responsible Two-Party System: A Report of the Committee on Political Parties. The APSA report was originally published as a supplement to volume 44, number 3 (1950) of the American Political Science Review, and made recommendations aimed at strengthening the party system such as increasing Congressional terms to four years. See Am. Pol. Sci. Ass'n, Toward a More Responsible Two-Party System: A Report of the Committee on Political Parties, 44 AM. POL. SCI. REV. 75 (Supp. 1950) (arguing that lengthening Representatives' term to four years would "promote legislative-executive party solidarity" by "synchronizing the terms of Representative and President").

11 For a further discussion of the political stability theory, see the sources cited in Hasen, supra note 4 , at $347-48$.

${ }^{12}$ For additional insight into the antifactionalism benefit of the two-party system, see the sources cited in $i d$. at 349 .

${ }^{13}$ For further elaboration on the voting cue argument, see the sources cited in id. at 349-50; see also Persily \& Cain, supra note 7, at 787 ("A polity without parties places a greater cognitive burden on individual voters and weakens the collective responsibility of political agents."). 
comprehend." ${ }^{11}$ Voters do not need to know anything about candidates besides their partisan affiliation in order to make a roughcut guess about each candidate's politics. Studies consistently have shown that Democratic politicians are more liberal and Republican politicians more conservative on a host of issues. ${ }^{15}$

As I explain in Part I.B below, the responsible party government scholarship described above has been roundly criticized for its failure to provide either empirical support for the first two claims or general normative justification for favoring the two-party system. The theory is especially vulnerable to criticism because it fails to take into account dramatic changes in the nature of political campaigns since the 1960s.

Nonetheless, the Supreme Court has proven itself quite enamored of the responsible party government position. Although earlier cases recognized that "[t]here is, of course, no reason why two parties should retain a permanent monopoly on the right to have people vote for or against them," the Court has moved steadily toward favoring a two-party duopoly. In the political patronage cases ${ }^{17}$ and in a case involving political gerrymandering, ${ }^{18}$ dissenting and concurring Supreme Court justices endorsed the concept that the state could promote the two-party system.

Supreme Court support for the two-party system reached majority status in 1997 when the Court decided Timmons v. Twin Cities Area New

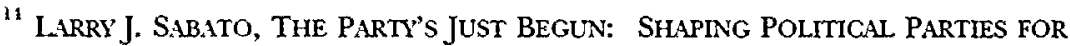
AMERICI'S FUTURE 8 (1988).

is For a summary of the evidence, see JOHN H. ALDRICH, WHY PARTIES? THE ORIgin and Transforalation of Political Parties IN AMierica 169-78 (1995). The voting cue argument is in tension with the political stability argument that the twoparty system produces nonideological parties tending toward the political center. Responsible party government scholars argue that there is enough room for debate at the political center for "tame ideological competition" between the parties. Hasen, inpra note 4 , at 350 .

1" Williams v. Rhodes, 393 U.S. 23, 32 (1968).

${ }^{17} S_{\ell}$, , f.g., Rutan v. Republican Party of IIl., 497 U.S. 62, 106 (1990) (Scalia, J., dissenting) ("It is self-evident that eliminating patronage will significantly undermine party discipline; and that as party discipline wanes, so will the strength of the two-party system."); Branti v. Finkel, 445 U.S. 507, 528 (1980) (Powell, J., dissenting) (contending that the use of patronage to fill various positions builds "party loyalty" and avoids party factionalism and splintering); Elrod v. Burns, 427 U.S. 347, 382 (1976) (Powell, J., dissenting) (claiming that patronage hiring practices contribute to the strong government interests in encouraging and strengthening stable political parties).

S Ste Davis v. Bandemer, 478 U.S. 109, 145 (1986) (O'Connor, J., concurring) ("The preservation and health of our political institutions... depends to no small extent on the continued vitality of our two-party system."). 
Party. ${ }^{19}$ Timmons concerned the question whether the state of Minnesota could prevent a minor party from endorsing the Democratic Party's nominee for the state legislature." That practice, called "fusion," is a tactic minor parties use to increase their popularity and leverage their political power in the few jurisdictions, like New York, that permit it.

The Supreme Court upheld the constitutionality of Minnesota's antifusion law. Among other arguments, ${ }^{21}$ the Court accepted the state's argument that "political stability is best served through a healthy two-party system." ${ }^{22}$ The Court remarked that the state may' enact election regulations that "temper the destabilizing effects of party splintering and excessive factionalism." ${ }^{23}$ Six Justices signed this opinion, and a seventh was willing to entertain the argument in a case where he believed the issue was presented properly. ${ }^{21}$

\section{B. Why the Major Parties Neither Deserve nor Need Special Constitutional Protection}

Current responsible party government scholars and the Supreme Court that has adopted their viewpoint are stuck in something of a time warp back to the 1950 s, when Schattschneider's ideas became mainstream orthodoxy. Alternatively, they are perhaps stuck in a time and space warp to early twentieth-century England. After all, the responsible party government scholars' model is that of the British

${ }^{19} 520$ U.S. 351,367 (1997) ("[T] he emergence of a strong and stable two-party system in this country has contributed enormously to sound and effective government." (quoting Davis, 478 U.S. at 144-45 (O'Connor, J., concurring))).

${ }^{20}$ For a more detailed description and analysis of the Timmons case, see Hasen, supra note 4 , at $337-41$.

${ }^{21}$ The Court accepted the state's argument that "a candidate or party could easily exploit fusion as a way of associating his or its name with popular slogans and catchphrases." Timmons, 520 U.S. at 365. It also agreed that permitting fusion would allow "minor parties to capitalize on the popularity of another party's candidate, rather than on their own appeal to the voters, in order to secure access to the ballot." Id. at 366. I criticize these rationales in Hasen, supra note 4, at 339. Like Justice Stevens in his dissent, I believe that the state's asserted interest in preserving the two-party system "appears to be the true basis for the Court's holding." Timmons, 520 U.S. at 377 (Stevens, J., dissenting).

${ }^{22}$ Timmons, 520 U.S. at 367.

${ }^{23} I d$.

${ }^{24}$ See id. at 384 (Souter, J., dissenting) (stating that "[i]f it could be shown that the disappearance of the two-party system would undermine [political stability], and that permitting fusion candidacies poses a substantial threat to the two-party scheme, there might well be a sufficient predicate for recognizing the constitutionality" of Minnesota's fusion ban). 
party system, "supposedly disciplined and cohesive, and unhampered by constitutional barriers in their governing function. ${ }^{, 25}$

Whether or not the scholars' model historically came close to representing reality in the United States or Great Britain, the model has ignored fundamental and permanent changes to the nature of campaigning since the $1960 \mathrm{~s}$ that have drastically altered the relationship among parties, candidates, and the voters. To understand these changes, it is useful to begin with political scientist V.O. Key's conception of the major parties as constituting three distinct elements: the party organization, the party-in-government, and the party-in-the-electorate. ${ }^{26}$

The nature of party organizations, such as the Democratic National Committee, has changed dramatically over time. ${ }^{27}$ Through the end of the nineteenth century, elections were party-centered affairs. Before the rise of the secret ballot at the end of the nineteenth century, each party printed up its own colored ballots, making it easy to determine the party allegiance of each voter and making it difficult for voters to do anything but vote a straight party ticket.

Even after the arrival of the secret ballot, campaigns remained party-centered because they were labor intensive. Turnout drives in major cities depended upon the workings of political machines, leading to the rise of political patronage.

Although some changes in party organizations may be traced to party reforms in the Progressive Era-including the important change to the direct primary discussed in Part I.C below-the most dramatic changes in the nature of party organizations came with technologydriven changes in campaigning. Television allowed major candidates to introduce themselves and their ideas to voters directly, lessening the need for a party cue. ${ }^{2 s}$ Television is an expensive medium that

2.5 DAVId E. PRICE, BRINGING BACK the PARTIEs 103 (1984). Considerable controversy remains over whether the British party system ever lived up to this ideal. Sir Erton M. Kirkpatrick, "Toward a More Responsible, Two-Party System": Political Science, Poliry Scimrt, or Pseudo-Science?, 65 AM. POL. SCI. REv. 965, 974-76 (1971) (questioning the view that the British party system is the ultimate embodiment of the responsible party model).

"S St $t^{*}$ KEY, sufra note 10, at 163-65 (setting forth multiple meanings of the term "political party").

$\Rightarrow 7$ For relevant citations, see Hasen, supra note 4 , at 350-55.

"In a 1998 survey, forty-one percent of California voters named television as the snurce of their political information. Mark Baldassare, Context and Setting: The Mood of th' Califoma Elertorate, in VOTING AT THE Political FAULT LINE: California's 
takes the place of party labor. These combined effects have moved campaigns from labor-intensive activities to capital-intensive ones." Even politicians running for lower-level offices run capital-intensive campaigns, spending much of their money on direct mail. ${ }^{30}$

In response to candidates' need for capital and media savvy over labor, party organizations have transformed themselves into fundraising machines and campaign consultants. Party organizations play an increasingly important role as the "party in service to its candidates." $^{\prime 1}$ The national Democratic and Republican party organizations are at the height of their power, raising ever-increasing amounts of money used to promote the candidates.

As party organizations have surged in importance in their new role as campaign consultants and fundraisers, the party-ingovernment, members of the same party serving in the legislature, appears to have strengthened as well, at least on the national level. One important measure of party-in-government strength is the extent to which party members vote together in Congress. Party cohesion or "unity scores" have been quite high, reaching unprecedented levels in 1994 and hovering around eighty percent for both parties in both chambers. ${ }^{32}$

In contrast to the rise of these other two elements of the parties, the party-in-the-electorate has died all but in name. This is not merely because patronage employment has declined over time, lessening the connection between party organizations and the voters who register with the parties. Voters are also both less likely to have strong identification with parties and more likely to see the parties as irrelevant. ${ }^{33}$ Only seven percent of Americans reported giving money

EXPERIMENT WTTH THE BLANKET PRIMARY (Bruce E. Cain and Elisabeth R. Gerber eds., forthcoming 2001) (manuscript at 94, 102-03) [hereinafter VOTING AT THE POLITICAI. FAULT LINE].

${ }^{29}$ New Deal legislation also lessened voter demand for political patronage jobs. See ALDRICH, supra note 15, at 268 ("New Deal legislation took over by policy and through entitlement the kinds of services local machines had once made available to woo support on election day.").

${ }^{30}$ See Hasen, supra note 4, at 352 n.125 (noting that House candidates spend their money on the expensive medium of direct mail advertising).

${ }^{31}$ ALDRICH, supra note 15, at 269.

${ }^{32}$ Id. at 176; see also Barbara Sinclair, Parties in Congress: New Roles and Leadership Trends, in The PaRTIEs Respond: CHANGes in AMERICAN PARTIEs ANd CaMipargns 299, 303 (L. Sandy Maisel ed., 2d ed. 1994) [hereinafter THE PARTIES RESPOND] (charting the significant increase of ideological cohesion in the Democratic House membership during the 1980s and early 1990s).

${ }^{33}$ See Martin P. Wattenberg, The Decline of American Polmicil Parties, 
to help a party or candidate in either of the last two elections, ${ }^{3 *}$ and only about two percent reported working for a party or candidate in the same period." Almost three-quarters of Americans reported not being contacted by one of the major political parties during campaigns in the same period. ${ }^{36}$ Aldrich has concluded that we no longer have "parties-in-the-electorate." ${ }^{37}$ We now have merely the "party in service to the candidate."

Given these fundamental changes, it is surprising that responsible party government scholars (and the Supreme Court, which currently seems to share their viewpoint) have not reconsidered whether the two-party system can play the important democratizing role with which it has been charged.

Despite the repeated claim that the two-party system promotes political stability, this contention remains unproven. Admittedly, the United States is a two-party system and politics here has been relatively stable." Nevertheless, it is not clear that the two-party system causes stability. Proof of instability in countries with many parties does not itself establish that the two-party system leads to stability. Indeed, Ronald Rogowski, in his examination of empirical evidence across countries, concludes that proportional representation, which tends toward multiple party systems, "best guarantees the stability of democratic policy." "1"

1952-1984, at 23, 46 (1986) (noting the declining salience of political parties in the American political process); see also AlDRICH, supra note 15, at 248-52 (discussing Wattenberg's arguments). The extent to which independent voters really lean towards one political party or the other appears to be overstated. See Steven Greene, The Pyrlological Sources of Partisan-Leaning Independence, 28 AM. POL. Q. 511, 530 (2000) ("[W] hen addressing general attitudes toward the parties and political independence, leaners should most appropriately be considered as independents. Leaners, in both their level of independent social identity as well as their attitudes toward parties in general, are indistinguishable from pure independents.").

National Election Studies, Center for Political Studies, Univ. of Mich., The NES Guide to Public Opinion and Electoral Behavior, 1995-1998, at http:// www.umich.edu/ nes/nesguide/toptable/tab6b_5.htm (last visited Jan. 20, 2001).

Id. at http://www.umich.edu/ nes/nesguide/toptable/tab6b_3.htm (last visited Jan. 20, 2001).

ld. at http://www.umich.edu/ nes/nesguide/toptable/tab6c_la.htm (last sisited Jan. 20, 2001).

ALDRICH, supra note 15, at 269.

Id.

"By "stable," I mean simply that we have peaceful, orderly transitions from one government to the next.

"' Ronald Rogowski, Trade and the Variety of Democratic Institutions, 41 INT'L ORG. 203, 209 (1987). 
The responsible party government scholars' claim that the twoparty system prevents interest group politics fares poorly in the era of capital-intensive campaigns. The parties' activities in raising unprecedented amounts of largely unregulated "soft money" belie the antifactionalist contention. The current system is little more than legalized money laundering: Candidates for federal office, who otherwise would be limited by the Federal Election Campaign Act from raising more than $\$ 1,000$ from individuals or $\$ 5,000$ from a political action committee per election, ${ }^{41}$ raise huge amounts of soft money from corporations, unions, and wealthy individuals. The parties serve as conduits for the sale of access by politicians for money to benefit their campaigns. At the very least, the prevalence of soft money raises serious questions about whether the parties are allencompassing coalitions preventing interest groups from seeking their narrow agendas. ${ }^{42}$

Only the voting cue benefit of political parties remains as a legitimate reason to favor the two-party system. The voting cue has declined in vitality: Since 1960, roughly one-third of all voters, on average, have split their votes between parties, as compared with only about three percent in $1900 .^{43}$ Split-ticket voters must be relying upon something other than party name in choosing candidates. Nonetheless, many of the voters who are not splitting their tickets may rely upon little more than the " $D$ " or " $R$ " next to a candidate's name, and some of the ticket-splitters probably use the party voting cue for most races about which they have little information.

The voting cue benefit of the two-party system alone, however, does not necessarily justify laws burdening the First Amendment rights of third parties. As I have argued in my analysis of Timmons, ${ }^{14}$ if the Supreme Court were concerned about the voting cue, it should have struck down, rather than upheld, Minnesota's antifusion law. Fusion prevents candidates from having more than one party label, thereby limiting information available to voters. A candidate with two-party (1994).

${ }^{41}$ Federal Election Campaign Act of 1971, 2 U.S.C. $\$ \$ 441 \mathrm{a}(\mathrm{a})(1)(\mathrm{A}) \&$ (a) (2) (A)

${ }^{42}$ For an in-depth look at the legal and policy issues surrounding soft money, see DANIEL H. LOWENSTEIN \& RICHARD L. HASEN, ELECTION LAW-CASES AND MLATERLILS (2d ed. forthcoming 2001) (manuscript ch. 16).

${ }^{43}$ See Morris P. Fiorina, The Electorate at the Polls in the 1990s, in THE PARTIES RESPOND, supra note 32 , at 123, 126 (containing a table setting forth percentages of congressional districts carried by House and presidential candidates of the different parties for the period 1900-1992).

${ }^{44}$ See Hasen, supra note 4, at 361-62 (criticizing the Court's decision in Timmons). 
labels (such as "Democrat" and "Liberal") sends a different cue than a candidate with only one (such as "Democrat"); the former is likely to be to the left of the latter. Antifusion laws prevent ballots from providing more precise voting cues.

The above analysis represents an argument that the two-party system does not deserve special protection by the courts, except perhaps when necessary to preserve the voting cue. ${ }^{45}$ The two-party system also does not need protection from the rights of minor parties and candidates."

Politicians have every incentive to join one of the two major parties. Political parties provide important organizational advantages to candidates, including economies of scale in campaigning and a party label that is useful to voters as a cue. They also provide ways for politicians to make long-term agreements to vote as a bloc in order to pass legislation that each politician individually favors. Unsurprisingly, virtually all state legislators and members of Congress are Democrats or Republicans. ${ }^{* ?}$

The preceding argument explains why politicians will join parties, but why only two parties? The answer lies in our system of elections, in which the winner is the candidate getting the most votes in a singleround election. "Duverger's Law" is the name that political scientists have given to the proposition that "first-past-the-post" or "plurality" voting systems lead to the emergence of a two-party system. ${ }^{\text {is }}$ In contrast, proportional representation systems are associated more with multiparty democracies.

Scholars have set forth a number of causal mechanisms for explaining Duverger's Law. One of the more persuasive arguments, put forward by Aldrich and Bianco, is that the two-party system

I find it hard to think of an example where the voting cue would be enhanced specifically' by a two-party, rather than a multiparty, system.

"For a more detailed presentation of this argument, see Hasen, supra note 4 , at 362-71.

${ }^{17}$ Ste id. at 366 (reporting that only one member of the 105 th Congress and $0.24 \%$ of state legislators elected in partisan elections were neither Democrats nor Republicans).

"Duverger was a French political scientist who made this claim in MAURICE DuNerger, Politicil Parties: Their Organization and ACtIVITy in the MODERN STITE 217 (Barbara North \& Robert North trans., Methuen \& Co. 3d ed. 1969) (1951) ("[T] he simple-majority single-ballot system favours the two-party system."). Duverger was not the first to note the relationship, see William H. Riker, The Twa-Party System and Dun'rger's Lau: An Essay on the History of Political Srience, 76 AM. POL. SCI. REV. 753, 75458 (1982) (tracing pre-Duverger history of idea), but he was the first to call it a "law." DUVERGER, supra, at 217. 
endures because politicians desire long and successful careers. Rational politicians recognize the "importance of affiliating with a party with a high probability of success for current and future contests," which, given the voting system in the United States, are the two major political parties. Given this evidence, it is difficult to imagine any election laws that would do less than eliminate plurality voting or single-member districts, seriously undermining the two-party system.

\section{Jones and the Weak Case for Major Party Control of the Form of Direct Primary}

The analysis in Parts I.A and I.B demonstrates that the conventional wisdom accepted by the responsible party government scholars and by a majority of the Supreme Court is at least unproven and likely flawed. States should not be allowed to discriminate against minor parties to favor the two-party system unless they can put forward more evidence of the system's benefits than the last generation of political scientists has been able to do.

Jones presents a more difficult issue, because there the state did not defend a law burdening third parties on grounds that it promotes the two-party system. Instead, the major parties themselves asserted First Amendment rights to association against a state law, passed by initiative, establishing a blanket primary. The major parties' First Amendment argument in a nutshell was that each party, as a private association, has the right to determine the rules for choosing which candidate will carry the party label in the fall election.

At first blush, the argument looks convincing; indeed, seven of the nine Supreme Court justices agreed that the state of California could not impose a blanket primary on the parties without their consent. A closer look at the issue, however, demonstrates that the First Amendment claim is much weaker than it initially appears.

I begin by recognizing that party organizations should have First Amendment rights of speech and association when they are conducting their own internal affairs. Thus, the Supreme Court was correct in the $1989 \mathrm{Eu}$ case in striking down a California law preventing political parties from endorsing candidates in primary

${ }^{49}$ John H. Aldrich \& William T. Bianco, A Game-Theoretic Model of Party Affiliation of Candidates and Office Holders, 16 MATHEMATICAL COMPUTER MODELING 103, 116 (1992). 
elections." Similarly, states should not be allowred to dictate the internal governance structure of the parties, as California tried to do in $E u$ by deciding that chairs of the state political parties had to alternate between residents of Northern California and Southern California." If other private organizations have the right to endorse candidates and structure their internal affairs, there is no reason to deny political parties the same constitutional protection. ${ }^{52}$

The same First Amendment rights are not, however, at stake when we consider the parties' direct involvement in the electoral process, such as participation in political primaries. To understand why, consider the following hypothetical situation. The people of the state of Pacifica, through initiative, decide that the issue of abortion is such a vital and strongly contested issue in the state that it is important for voters to know where all candidates stand on the issue. Accordingly, the initiative abolishes partisan primaries ${ }^{53}$ and establishes a new kind of primary. For purposes of the primary, voters get to register as either "pro-choice" or "anti-abortion." Candidates similarly identify themselves on the ballot as either "pro-choice" or "anti-abortion." "Pro-choice" voters get to choose among the "pro-choice" candidates, and "anti-abortion" voters get to choose among the "anti-abortion" candidates, with the top vote-getter in each category appearing on the general election ballot. ${ }^{5.4}$ In response to this new law, two organizations develop. The first, intending to help "pro-choice" candidates, is called the Pacifica Abortion Rights Action League

Eu v. S.F. County Democratic Cent. Comm., 489 U.S. 214, 229 (1989).

If. at 232-33.

"Lowenstein disagrees with this assessment of Eu, claiming that courts should not intervene in what are essentially "intraparty" disputes between the party in government (the California state legislature controlled by Democrats in the case of $E u$ ) and the Democratic party organization. Daniel H. Lowenstein, Associational Rights of Major Political Partivs: A Skeptical Inquin; 71 TEx. L. REV. 1741, 1786 (1993). Lowenstein achnowledges that "a party faction, dominant in the legislature, conceivably could adopt rules so flagrantly discriminatory or oppressive that judicial intervention would be appropriate," but he argues that the rules at issue in Eu "certainly do not come close" to that kind of oppression. Id.

Party organizations could still endorse candidates, but the party label would not appear on the ballot and primaries would not be conducted along party lines. Certainly abolition of the partisan primary is constitutional because parties have no entitlement to such a primary. The Supreme Court in Jones observed that California could enact a nonpartisan primary to reach its goals of moderation without infringing on the First Amendment rights of political parties. Jones, $120 \mathrm{~S}$. Ct. at 2414.

To avoid potential constitutional problems with the rights of minor parties and independent candidates, assume that independents and third-party candidates may also appear on the general election ballot if they obtain enough petition signatures. 
(PARAL). The second, intending to help "anti-abortion" candidates, is called the Pacifica Right to Life Committee (PRLC). PARAL and PRLC are private associations with their own rules of internal governance.

A few years later, the voters of Pacifica decide that the primary process established by initiative is producing candidates that are too extreme on the abortion issue. During the primaries, those voters who feel most strongly one way or the other on the abortion issue turn out to vote and tend to choose candidates who have the strongest positions on this issue as well. This leaves voters without a moderate choice on the abortion issue in the general election.

Accordingly, the voters pass a new initiative continuing the procedure whereby candidates identify themselves on the primary ballot as either "pro-choice" or "anti-abortion" and voters register in one category or the other. Under the new initiative, however, voters-regardless of whether they register as "pro-choice" or "antiabortion"-may vote for a candidate in either primary. The winners in each category still go on to the general election. The likely effect of this new initiative is the election of candidates more moderate on the issue of abortion. ${ }^{55}$

After the initiative passes, PARAL and PRLC bring suit, contending that the initiative violates their First Amendment right to association. Surely they would lose their First Amendment challenge. Nothing in the new initiative prevents these groups from endorsing candidates or interferes with their internal governance. The groups have as much autonomy as they wish. Neither group may be happy that the new initiative leads to candidates more moderate on the issue

${ }^{55}$ Gerber explains why the blanket primary may lead to more moderate candidates running for office: "By opening participation in the primary to voters outside a candidate's party, candidates are forced to compete for the ideological center of the electorate. Candidates with more moderate positions, or who can move to the center, receive greater support and prevail." Elisabeth R. Gerber, Strategic Voting and Candidate Policy Positions, in VOTING AT THE POLITICAL FAULT LINE, supra note 28 (manuscript at 291, 291). Gerber explains that opponents of the blanket primary claimed that it advantages extremist candidates because it allows "raiding" or 'sabotage' by ideologically motivated partisans. These voters nominate weak candidates in the other party and their own ideologically polar candidate prevails." Id. at 292. Examining the empirical evidence in light of the June 1998 California blanket primary, Gerber found "some evidence for the moderation hypothesis and little evidence for the polarization hypothesis." Id. at 314. For additional evidence across states, see Elisabeth R. Gerber \& Rebecca B. Morton, Primay Election Systems and Representation, 14 J.L. ECON. \& ORG. 304 (1998), summarizing evidence that participation by a wider spectrum of the electorate leads to the election of more moderate candidates. 
of abortion. The initiative therefore may be bad policy, but that cannot serve as the basis for their First Amendment challenge.

Why is the situation of the major parties in California's blanket primary any different? Like the fictitious organizations in my hypothetical, the California Democratic and Republican parties have not been told how to run their organizations. Nor does anything prevent these organizations from endorsing candidates. The party organizations, like PARAL and PRLC, have as much autonomy as they wish, though they too may be upset that the new initiative leads to candidates being more moderate on issues important to the parties.

Proponents of party autonomy may make three arguments to distinguish my hypothetical situation from the situation of the major parties in Jones. First, they may argue that in the hypothetical, voters in the general election choose a candidate identified simply as "prochoice" or "anti-abortion," not as the "PARAL" or "PRLC" candidate. In California, by contrast, voters in the general election would choose a candidate dubbed the "Democratic" or "Republican" nominee of the party. Thus, the candidate is identified by the party organization's party label.

This difference, while real, should not be constitutionally significant. Voters and members of the party organization all understand that the voters, not members of the party organization, are choosing the candidate who appears on the general election ballot using the "Democratic" or "Republican" party label. It has been this way since the Progressive movement successfully pushed for the adoption of the direct primary, whereby voters, rather than party organization members, choose party nominees.

Thus, the majority in Jones was incorrect to analogize the situation of the party organizations to the parade organizers in Hurley $v$. IrishAmerican Gay, Lesbian and Bisexual Group of Boston. ${ }^{56}$ In Hurley, the Supreme Court held that organizers of a parade could not be forced by state law to include parade participants with whom the organizers disagreed politically. ${ }^{57}$ The Court held that such forced association violates the First Amendment. ${ }^{3 s}$ In a political primary, however, the choice of candidate is that of the voters, not of the party organization. The party organization is not forced to associate with the nominee

515 U.S. 557 (1995), cited with approval in Jones, 120 S. Ct. at 2412.

Hules, 515 U.S. at 578.

Id. at 581 ("Our holding today rests ... on the Nation's commitment to protect freedom of speech."). 
chosen by the voters: The party organization needs neither to work for nor to endorse the nominee, though it often will do so. ${ }^{59}$

Moreover, the blanket primary system is not the only one in which those eligible to vote for party candidates may include more than those people who have had a longstanding affiliation with the party. In some open primary states, for example, voters choose on the day of the election whether to affiliate with the Democratic or the Republican party in order to get a ballot with the names of one party's candidates or the other's. ${ }^{60}$ Even in states with completely closed primaries, where one must register in advance for one party or the other and can vote only in that party's primary, the party organizations have no control over who registers with each party and how party registrants vote. ${ }^{61}$

Given how easy it is for voters across the range of primary types to affiliate with a political party solely for the purpose of voting in the primary, it rings hollow for the parties to single out the blanket primary as somehow changing or undermining the essence of the

${ }^{59}$ In $E u$, the Court recognized that the right of parties not to endorse candidates was so important because it is possible for a candidate "with views antithetical to those of her party nevetheless to win its primary." Eu v. S.F. County Democratic Cent. Comm., 489 U.S. 214, 217. The Court noted that in 1980, a Grand Dragon of the Ku Klux Klan named Tom Metzger won the Democratic Party's nomination to Congress from the San Diego area. Id. at 217 n.4. In a case involving another avowed white supremacist, the United States Court of Appeals for the Eleventh Circuit held that the Georgia Republican Party had the right to keep candidate David Duke's name off the ballot in the Georgia presidential primary under its rights of political association. See Duke v. Massey, 87 F.3d 1226 (11 th Cir. 1996) (holding that exclusion did not violate First and Fourteenth Amendment rights of the candidate and his supporters). For reasons explained in the text above, I believe the Court of Appeals was incorrect in finding that the party has such a right.

${ }^{60}$ Those voters must vote for all candidates in one party, in contrast to voters in the blanket primary, who may vote, for example, in the Democratic primary for governor and the Republican primary for attorney general. The Supreme Court in Jones refused to decide whether a state could impose an open primary on a political party without its consent. $120 \mathrm{~S}$. Ct. at $2410 \mathrm{n} .8$. The logic of Jones, however, implies that a state may not do so. See id. at $\mathbf{2 4 2 0}$ (Stevens, J., dissenting) ("[T] here is surely a danger that open primaries will fare no better against a First Amendment challenge than blanket primaries have."); see also DANIEL H. LOWENSTEIN \& RICHARD L. HASEN, ELECTION LAW, 2000-2001 SUPPLEMENT 51 (2000) (arguing that Jones and an earlier Supreme Court case "give the parties rather than the state legislatures the last word" on the form of party primary, but noting that "the state legislature usually will provide for the type of primary favored by the major parties").

il Ever since the White Primary Cases, it has been unconstitutional for parties to exclude people from the vote on the basis of race. See DaniEL H. LowENSTEIN, ELECTION LAW 318-21 (1995) (detailing the history of the obligations of political parties under the Constitution). 
party or capturing the party's message..$^{62}$ To the extent that members of party organizations object to certain voters participating in the decision over who bears the "Democratic" or "Republican" label, they are really arguing against the direct primary itself and in favor of other systems of choosing party nominees, such as caucuses. ${ }^{63}$

Yet the Supreme Court in Jones rejected the idea that the direct primary itself is unconstitutional: "We have considered it 'too plain for argument,' ... that a State may require parties to use the primary format for selecting their nominees, in order to assure that intraparty competition is resolved in a democratic fashion." should logically have followed that the state could decide how voting in the direct primary should be conducted. So long as no one requires a party organization to endorse or otherwise affiliate with a particular candidate, there should be no constitutional problem.

A second and related argument distinguishing my hypothetical from the Jones case is that voters in the hypothetical merely label themselves as "pro-choice" or "anti-abortion" rather than as members of PARAL or PRIC; in contrast, voters in the traditional primary identify themselves as members of the parties by registering as a "Democrat" or "Republican." Voters thus "join" each party as the "party-in-the-electorate" to instruct the party organization regarding who the party nominee should be; voters in my hypothetical do not join PARAL or PRLC to instruct each organization how to vote.

Under this view (and the view of the majority in Jones), the primary election is a "party affair." ${ }^{65}$ The blanket primary, by allowing

"' S S $\ell^{\prime}$ Jone's, $120 \mathrm{~S}$. Ct. at 2421 (Stevens, J., dissenting) ("In my view, an empirically debatable assumption about the relative number and effect of likely crossover voters in a blanket primary, as opposed to an open primary or a nominally closed primary with only a brief preregistration requirement, is too thin a reed to support a credible First Amendment distinction."); Brennan Center Brief, supra note 6, at 7 ("An empirically debatable assumption about the relative number of likely crossover voters in an open primary, as opposed to a blanket primary, is, however, a thin reed on which to base a First Amendment distinction.").

"St' Lowenstein, supra note 52, at 1768 ("Recognizing that there is very little popular sentiment for eliminating primaries, some party renewal advocates have argued that laws requiring primaries are unconstitutional."). The move to the direct primary began as a progressive reform in 1903 and was adopted by most states by the 1920s. Hasen, supra note 4, at 353 n.129 (citing WALTER DEAN BURNHAM, CRITICAL ELECTIONS AND THE MLAINSPRINGS OF AMERICAN POLITICS 75 (1970)).

'.4 Jones, 120 S. Ct. at 2407; see also Lightfoot v. Eu, 964 F.2d 865 (9th Cir. 1992) (rejecting a challenge to California's direct primary).

Jonts, $120 \mathrm{~S}$. Ct. at 2407 n.4 (disputing the idea that an election is solely a "public affair" and stating that "when the election determines a party's nominee it is a party affair as well"). 
non-party members to participate in the party's primary, interferes with the party's right to determine its own candidates. This argument fails, however, because it relies upon the myth that the party-in-theelectorate still exists and that party registration remains a significant associative act.

In fact, party registration is the functional equivalent of simply identifying oneself as "pro-choice" or "anti-abortion" as a means of voting in Pacifica's primary. Generally one chooses "Democrat" if one is more liberal or if one's parents were registered as Democrats and "Republican" if one is more conservative or if one's parents were registered as Republicans. ${ }^{66}$ It is a way to signal to the parties that one wants to receive political information from the more appropriate point on the political spectrum.

As noted in Part I.B, the party-in-the-electorate no longer exists as anything more than a political science construct; one does not really "join" a party by registering to vote with a party affiliation. Few voters have contact with, much less contribute time or money to, the political parties with whom they register. Voters are consumers who choose candidates in elections, with some relying upon the party label as a useful shortcut to discern the candidates' likely views of public policy. Thus, registering with a party is no more of a significant associational fact for First Amendment purposes than labeling oneself as "pro-choice" or "anti-abortion" in my Pacifica hypothetical.

Finally, one might argue that the blanket primary is constitutionally distinguishable from my hypothetical situation because parties are special kinds of organizations serving important societal goals, not single interest groups like PARAL or PRLC. Parties, therefore, are entitled to greater First Amendment protection than would be afforded to other private associations like PARAL or PRLC. Under this argument, the blanket primary, by leading to the election of more moderate candidates, endangers the parties' special role by blurring party lines.

As a matter of policy, there may be something to the argument that the blanket primary is a bad idea. Although I have rejected the political stability argument for the two-party system as unproven and the antifactionalism argument for the two-party system as incorrect, I have acknowledged that the voting cue remains important for a number of voters who pay little attention to politics. As more 
moderate candidates are chosen, the voting cue may become less relevant. In addition, evidence from the California experience suggests that the blanket primary helps incumbents even more to reelection."

This is, however, a policy argument against adopting the blanket primary. As a matter of policy there may be good reasons to oppose the blanket primary, but a policy argument is not a First Amendment argument. The state, and particularly voters through the initiative process, should be allowed to choose whether to take a chance on losing any' societal benefits that might accompany a strong two-party system in order to get other benefits such as the election of more moderate candidates. ${ }^{\text {is }}$ Evidence suggests that the blanket primary also may help the position of Latinos and other minorities. ${ }^{69}$ It also may boost turnout, at least slightly. ${ }^{70}$

Perhaps the Supreme Court could have turned this policy argument into a constitutional one. ${ }^{71}$ The Court could have said (but

"Si" Bruce E. Cain \& Elisabeth R. Gerber, Conclusion, in VoTING AT THE POLITICAL FAULT LINE, supra note 28 (manuscript at 520, 534) (noting the "enhanced incumbency effect" from the blanket primary).

"It even could be supported on partisan grounds. Moderate Republican Congressman Tom Campbell of California actively worked toward the passage of the blanket primary initiative after losing to a more conservative candidate in the Republican primary for U.S. Senate. Campbell believed that Republicans would do better under an open primary because candidates chosen there would be more likely to appeal to the majority of voters in the general election, and not just to a majority of Republican primary voters. See Brian J. Gaines \& Wendy K. Tam Cho, Crossover Voting Before the Blauke: Primaries Versus Parties in Califormia Histom, in VoTING AT THE Politicil FidLT LINE, supra note 28 (manuscript at 14, 41-43) (describing endorsements of Proposition 198 by political figures and their motivations).

"S Sw Gary MI. Segura \& Nathan D. Woods, Targets of Opportunity: California's Blankst Pnmay and the Political Representation of Latinos, in VOTING AT THE POLITICAL FICLT LINE, supra note 28 (manuscript at 376,377 ) (suggesting that "the switch to the blanket primary has already begun to bear fruit for Latino political interests"); see also Miki Caul \& Katherine Tate, Thinner Ranks: Women Candidates and Califormia's Blanket Priman, in VOTING AT THE POLITICAL FAULT LINE, supra note 28 (manuscript at 355, 367) (finding no evidence supporting the thesis that the blanket primary has hurt the election of women candidates).

"Ste Wendy K. Tam Cho \& Brian J. Gaines, Candidates, Domors, and Voters in Califomia's First Blanket-Primary Elections, in VOTING AT THE POLITICAL FAULT LINE, supra note 28 (manuscript at 249, 256) (attributing a $2.4 \%$ turnout boost in voter participation to the blanket primary).

"For a strong argument that the courts focus on the role of parties in democracy sather than the constitutional text in adjudicating the claim in Proposition 198, see Samuel Issacharoff, Private Parties with Public Purposes: Political Parties, Associational Frridoms, and Partisan Competition, 101 Colvar. L. REv. (forthcoming 2001). For an argument that parties should not enjoy "a preferred constitutional position under the First Amendment," see Frank J. Sorauf, Strength Through Financial Wizardry: 
did go so far in Jones to say) that parties are entitled to special First Amendment rights. As a matter of constitutional doctrine, this would be a difficult argument for the current Court to make. There is nothing in the text of the Constitution giving parties special First Amendment rights; indeed, parties are not mentioned at all because parties as we now know them did not exist at the time of the writing of the Constitution. ${ }^{72}$ The Court certainly could have done so less explicitly, however. My reading of the Court's patronage cases is that, although the Court framed those cases as involving the First Amendment rights of employees not to affiliate with a political party, it was less concerned with the First Amendment than it was with ending the corruption that has been associated with political patronage. $^{73}$

If the Court, however, is going to accept-explicitly or implicitlypolicy arguments as a means of adjudicating First Amendment rights, it should also look closely at the extent of the evidence supporting the policy arguments. The evidence we have on the effect of the form in which primary elections are held on the strength of parties does not demonstrate that parties are in great danger from more open primaries. Despite the existence of the blanket primary in the State of Washington for many years, the Republican Party there is among the strongest party organizations in the nation. ${ }^{74}$ More generally, during the same period that almost half of the states had open or blanket primaries, party cohesion in Congress reached high levels unprecedented in American history. It appears that the openness of the primaries has not caused candidates to become so moderate that

Problems and Dilemmas for the Major American Parties 18 (unpublished paper prepared for delivery at the 2000 annual meeting of the American Political Science Association) (on file with the University of Pennsylvania Law Review), stating that "it is a position tantamount to arguing that, of all political actors and organizations, the parties must enjoy absolute First Amendment protection, that they alone must be protected by the Amendment from any limiting legislation."

${ }^{72}$ See Larry Kramer, After the Founding: Political Parties and the Constitution (unpublished manuscript, on file with author) (arguing for constitutional recognition of political parties).

${ }^{73}$ See Richard L. Hasen, Patronage, in 4 ENCrClopediA OF THE AMERICIN CONSTITUTION 1885, 1886 (Leonard Levy et al., eds., 2d ed. 2000) ("Though the debate over the constitutionality of patronage turns in part upon the Justices' varied beliefs about how coercive or unfair a party affiliation requirement is to government employees or contractors, the most contentious issue appears to be whether patronage practices support a strong, democratic government.").

${ }^{74}$ Cal. Democratic Party v. Jones, 169 F.3d 646, app. at 659 n.29 (9th Cir. 1999), rev'd, 120 S. Ct. 2402 (2000). 
they cannot engage in party-line voting most of the time. ${ }^{75}$

Stating that the parties should not have a constitutional right to veto the state's choice of primary would not at all mean that the parties would be without influence over the choice. In fact, the parties already have pervasive influence over the choice. In those states without the initiative process, the state legislature can decide on the form of the primary or at least can propose a state constitutional amendment to change the form of the primary. Almost all the members of almost every state legislature are Democrats and Republicans, who likely will be amenable to their party leadership's choice of primary.

Even in states with the initiative process, parties can try to convince voters not to adopt more open primaries. Parties can themselves propose initiatives to close the primaries. In California, the Democratic and Republican parties did not seriously contest Proposition 198, the initiative establishing the blanket primary. They spent almost nothing and devoted very few resources to the issue; whereas, they participated heavily in the initiative process when they saw partisan electoral advantage. For example, Republicans spent heavily in support of an anti-affirmative action initiative, and Democrats spent heavily in opposing an anti-welfare reform initiative. Had the parties fought Proposition 198, they might have been successful.

If anything, the evidence of the two major parties' pervasive control over the political process should militate toward lesser, rather than greater, First Amendment protection for the parties in the electoral process. The parties have the political means to protect themselves; as Lowenstein has remarked, the parties are "grown-ups" who should be expected to take care of themselves.

Court protection of the major political parties is appropriate in one situation involving the electoral process: Courts should protect a major party when the other major party uses its control over the state

Haeberle found that, when controlling for other factors, the openness of the primary had no effect on the party cohesion scores of members of Congress. Steven $H$. Haeberle, Clost Primaries and Party Support in Congress, 13 AM. POL. Q. 341, 350 (1985).

"For a detailed look at the California parties' strategies regarding Proposition 198, sec Richard L. Hasen, Partiks Take the Initiative (and Vice Versa), 100 ColuM. L. REv. $731,745-48$ (2000), demonstrating through an examination of Proposition 198 how the parties are still behind the learning curve on countering initiatives that regulate the parties themselses.

"Lowenstein, sufra note 52, at 1790. 
legislature to engage in an act of unfair competition. ${ }^{78}$ This situation is illustrated by the case of Tashjian $v$. Republican Party of Connecticut." In Tashijan, the Connecticut Legislature, controlled by the Democratic Party, prevented the Republican Party from opening up their primaries to independent voters. Court scrutiny was appropriate in Tashjian because there the state, controlled by one major party, was discriminating against the other party for partisan advantage, ${ }^{80}$ much like a partisan gerrymandering claim under Davis v. Bandemer. Scrutiny was not appropriate, however, on grounds that the Connecticut law infringed upon the Republican Party's right to autonomy.

Professor Cain's two primary errors (pun intended) in his wellargued article in this volume are (1) his belief that a contrary ruling in Jones would have locked in a hypercentrist electoral process, ${ }^{s 2}$ and (2) his view that the state must come forward with a compelling interest to justify its choice of a blanket primary. ${ }^{83}$ The first belief is incorrect because voters would have retained the right to overturn Proposition 198 in a subsequent election, a point recognized by the lower courts in Jones. ${ }^{84}$ Professor Cain laments the tyranny of the majority over the minority, terming it "majority abuse," "minority" is really the major political parties who remain the dominant political forces in the state. As I have detailed elsewhere,"

${ }^{7 s}$ Of course, when voters act through the initiative process as they did in Jones, we can safely ignore the problem.

${ }^{79} 479$ U.S. 208 (1986).

${ }^{\text {so }}$ Id. As Lowenstein points out, however, there might be good policy reasons for the courts to reject the Republican claims in such a case. See Lowenstein, supra note 52, at $1789-90$ (discussing reasons for the Court to intervene "at the behest of a minority party that complains of a provision affecting both parties uniformly").

81 478 U.S. 109 (1986).

${ }^{82}$ Bruce E. Cain, Party Autonomy and Two-Party Electoral Competition, 149 U. PA. L. REv. 793, 795 (2001).

${ }^{83} I d$.

${ }^{84}$ [T] he court does not decide whether a blanket primary is a good idea; it may prove to be a bad idea, in which case the people of the State presumably will act to reform the system in the future as they have in the past. Nor does the court decide whether the voters were correct in concluding that a more representative and participatory system is desirable at this time in the State's history or whether it is wise to weaken the parties by some degree to further the goals of representativeness and participation. These important questions are for the people of the State to decide.

Jones, 169 F.3d 646, app. at 662 (9th Cir. 1999), rev'd, 120 S. Ct. 2402 (2000).

${ }^{85}$ Cain, supra note 82 , at 808 .

${ }^{86}$ Hasen, supra note 76 , at $747-48$. 
the parties in California used numerous devices to circumvent Proposition 198, and easily could have placed a measure on the ballot to overturn it and devoted resources toward its repeal. ${ }^{87}$ "Lock-in" occurs when political arrangements are immune from change by the political process; the blanket primary story in California does not fit that category.

Professor Cain's second error is his assumption that the state must come forward with a "compelling interest" to justify its (perhaps misguided) policy choice toward candidate moderation. His argument presupposes a violation of rights; otherwise, it is difficult to see why the government is not free to choose moderation. Cain does not hang his hat on a rights-based approach, however, preferring instead a "functional" view of the political process. Such a position is certainly defensible," but then we need to cut the discussion of compelling interests and simply argue over what is the best policy. In essence, what Professor Cain is advocating is that courts bias outcomes toward the status quo because the status quo represents good political process. Unless Professor Cain is that political scientist he describes who has received divine guidance on the best form of democratic government, ${ }^{\text {s. }}$ I do not see why his view rather than a view of the majority of state voters should get enshrined in constitutional doctrine. It seems that he should bear the burden of producing compelling evidence that the voters' choice will harm democracy in the long term.

\section{THE CASE FOR COURT PROTECTION OF MINOR PARTIES}

Part I argued that neither the "two-party system" nor the

In my Colunbia Law Review article, I explain how the parties did the former in convincing the California legislature to place Proposition 3 on the ballot. Proposition 3 would have reversed the blanket primary for the presidential nomination process. The parties then devoted virtually no resources toward passing it, and Proposition 3 failed. See id. The parties then got around the blanket primary for the presidential nomination process through legislation passed in the California legislature requiring the coding of ballots by voters' party affiliation, thereby allowing parties to ignore the results of the blanket primary.

Str Samuel Issacharoff \& Richard H. Pildes, Not by "Election Law" Alone, 32 Loy. L.A. L. REX. 1173, 1183 (1999) ("[T] he central question is how deep into existing practices a robust, functional, historically-aware understanding of demacracy will penetrate."); Daniel R. Ortiz, From Rights to Arrangements, 32 LoY. L.A. L. REv. 1217, 1217-18 (1999) (praising the movement of election law scholarship from a rights-based approach "to a more pragmatic and structural view of politics as a matter of institutional arrangements").

Cain, supra note 82 , at 813 . 
Democratic and Republican parties need or deserve judicial protection most of the time. In this Part, I argue that minor parties (and independent candidates ${ }^{90}$ ), in contrast to the major parties, do deserve and need such protection.

My argument has three components. First, the government rarely has a legitimate, much less compelling, reason to place onerous burdens on minor parties. Second, the precarious and fragile position of third parties justifies enhanced First Amendment protection. Third, minor parties play an important role in our electoral process by enriching political debate and thereby providing an additional reason for protection.

I begin my first argument with reference to Jones. Recall that the reason voters in California likely passed the blanket primary was to elect more moderate candidates in the general election. As we know, the blanket primary encourages Democratic and Republican candidates to move to the political center. No doubt voters, in passing the open primary, were hardly voting for it in order to promote more moderate minor party candidacies." Minor party candidates almost never win elections in California, ${ }^{92}$ nor are they a political factor in the overwhelming majority of elections. Thus, there is not much of a government interest at stake when it comes to regulating minor parties' primaries.

Jones, of course, was an initiative case. Much of the enacted legislation that affects minor parties, however, is passed by legislatures, not by the people through the initiative process. The most common way that legislatures pass laws affecting minor parties is through the passage of tough ballot-access requirements or related laws like the antifusion law in Timmons.

Courts should scrutinize these requirements carefully because the legislature that passes them is made up almost entirely of Democrats

${ }^{90}$ Although what I say about minor parties also applies to independent candidates, I will simply use the term "minor parties" for the rest of this Article.

${ }^{91}$ See Shaun Bowler \& Todd Donovan, Political Reform Via the Initiative Process: What Voters Think About When They Change the Rules, in VOTING AT THE POLITICAL. FAULT LINE, supra note 28 (manuscript at 55, 72) (finding that voters with strong party feelings toward the major parties opposed the initiative and those with weak ties supported the initiative). Interestingly, the authors found that voters registered with minor parties were significantly more likely to support Proposition 198. Id. at 73.

${ }^{92}$ See Christian Collet, Openness Begets Opportunity: Minor Parties and the First Blanket Primary in Califormia, in VOTING AT THE POLITICAL FAULT LINE, supra note 28 (manuscript at 326, 326) (noting the first minor party candidate since 1917 was elected to the California state assembly in 1999). 
and Republicans," who have a common interest in maintaining high barriers to entry by other parties. Casually asserted general state interests in preventing voter "confusion" or "fatigue" should not be taken at face value. The state does have a legitimate interest in having a manageable ballot and electoral system, but courts should ensure that the legislature has good empirically justified reasons for enacting ballot-access laws and other laws affecting minor parties. Requirements imposed on minor parties should not be permitted if their only purpose is to entrench the two-party duopoly. ${ }^{94}$ Had the Supreme Court insisted on such evidence in Timmons, ${ }^{95}$ for example, the result might have been different. In most cases, the state has no good reason to impose severe burdens on minor parties.

Beyond the lessened government interest in regulating minor parties, minor parties are in much greater need of protection than the major parties. Minor parties do not have easy recourse to the legislature or the executive, for example, when the people act by initiative. Minor parties are likely to be ideologically driven groups, and sometimes their ideologies are unpopular. Enhanced judicial review is especially appropriate for politically vulnerable groups, termed "discrete and insular minorities."

Additionally, to the extent that courts should explicitly or implicitly take social policy into account in evaluating First Amendment claims," strong social policies support protection of minor political parties. To understand why, we must consider the function of minor parties in American democracy.

Minor parties generally are not formed in the United States for the purpose of winning elections. Most minor party candidates are well aware of Duverger's Law and have no illusions of taking office. Nor do minor parties have much chance of displacing one of the two major parties. The last time that such a displacement occurred was in the 1850 s, when the Republicans replaced the Whigs. ${ }^{97}$

Ste' Hasen, supra note 4, at 366 (providing statistics on how few minor party candidates are elected to Congress and the state legislatures).

"The Supreme Court has held that empirical evidence is not required in such circumstances. Ser Munro v. Socialist Workers Party, 479 U.S. 189, 195 (1986) (holding that a requirement to make such a showing of empirical evidence "would invariably lead to endless court battles over the sufficiency of the "evidence").

"St' supra text accompanying note 44 (discussing the author's view of Timmons).

"th" Sit supra text accompanying note 71 (arguing that the Supreme Court could have turned a policy argument against the blanket primary into a constitutional argument).

${ }^{17}$ SORUUF \& BECK, supra note 66 , at 35 . 
Instead, minor political parties broaden the political debate." They raise otherwise ignored issues, prompting the major parties to take positions on these issues. Anyone who remembers the 1992 presidential race will recognize the important role that Ross Perot played in putting deficit reduction on the table. Perot cannot be credited with the budget surpluses of recent years, but one wonders whether President Clinton and the Republicans in Congress would have made the same budgeting decisions if they had not been influenced by Perot's discussion of these issues.

As Justice Marshall explained in his dissenting opinion in Munrov. Socialist Workers Party:

The minor party's often unconventional positions broaden political debate, expand the range of issues with which the electorate is concerned, and influence the positions of the majority, in some instances ultimately becoming majority positions. And its very existence provides an outlet for voters to express dissatisfaction with the candidates or platforms of the major parties.

Given these three factors-lessened government interest in regulation, the political vulnerability of minor parties, and the social benefits they provide to the electoral process-greater court protection is warranted.

Deciding precisely how much protection minor parties should receive is a difficult question, as the Jones case illustrates. As already mentioned, the state had little reason to subject minor parties to the blanket primary, suggesting that it is unconstitutional not to exempt them. On the other hand, the state, in enacting the law, did not impose a huge burden on minor parties. It is true that in a number of contests in California under the blanket primary, the minor parties had their votes swamped by crossover voters. ${ }^{100}$ If my analysis in Part I.C is correct, however, this factor does not interfere with minor parties' First Amendment right to association; minor parties can simply disavow the chosen candidate or not work toward her election.

The answer to resolving this question may turn on how the

${ }^{98}$ As the leading text on third parties has put it:

[T] he power of third parties lies in their capacity to affect the content and range of political discourse, and ultimately public policy, by raising issues and options that the two major parties have ignored. In so doing, they not only promote their cause but affect the very character of the two-party system.

STEVEN J. ROSENSTONE ET AL., THIRD PARTIES IN AMIERICA 8 (2d ed. 1996).

${ }^{99}$ Munro, 479 U.S. at 200 (Marshall, J., dissenting).

${ }^{100}$ See Collet, supra note 92, at 332-37 (discussing the impact of the blanket primary on minor parties in 1998). 
blanket primary interferes with the social function of minor parties. Evidence suggests that even minor party candidates moderate their positions in blanket primaries. ${ }^{111}$ This moderation lessens the chance that minor parties will raise additional issues to be put on the table for consideration by the major party candidates. For this reason, court protection probably is warranted, but reasonable minds could disagree.

\section{CONCLUSION}

This Article has made the normative case that courts offer the major parties too much protection and minor parties too little. It has not considered in detail the positive question whether courts in fact do protect major or minor political parties. Such an examination would reveal that courts in fact are much more prone to protect major parties than minor parties, the exact opposite result than that urged here.

Jones continues the Supreme Court tradition of Eu and Tashjian by protecting party organizations from infringements by the state. The result in Jones would have been more palatable had the Court been more thoughtful about what role the people should be allowed to play in structuring the electoral process in an era where the party-in-theelectorate no longer exists.

I'1 $S_{\text {to }}$ id. at $341-42$ (discussing how candidates in blanket primaries are encouraged to "engage the mainstream electorate"). 
